\title{
DROPLETS FROM THE PLANKTON NET
}

AUTHOR(S):

Tokioka, Takasi

CITATION:

Tokioka, Takasi. DROPLETS FROM THE PLANKTON NET. PUBLICATIONS OF THE SETO MARINE BIOLOGICAL LABORATORY 1954, 4(1): 99-102

ISSUE DATE:

1954-11-20

URL:

http://hdl.handle.net/2433/174497

RIGHT: 


\title{
DROPLETS FROM THE PLANKTON NET ${ }^{1)}$
}

\author{
TAKASI TOKIOKA
}

Seto Marine Biological Laboratory, Sirahama

XIV. On a Small Collection of Chaetognaths from the Central Pacific. (Fig. 18)

A small collection of chaetognaths, hauled by KITAHARA's quantitative plankton net or young fish tow-net from $100 \mathrm{~m}$ to surface near the Phoenix and Gilbert Islands during the period from February to March 1953, was submitted to me for examination by the courtesy of Prof. T. CHIBA and Mr. S. Tsuruta of the Simonoseki College of Fisheries, to whom I wish to express here my hearty thanks for their kindness. This material comprises the following nine forms:

Species

1. Sagitta hexaptera

2. Sagitta enflata

3. Sagitta bipunctata

4. Sagitta robusta

5. Sagitta ferox

6. Sagitta serratodentata pacifica

7. Sagitta regularis

8. Pterosagitta draco

9. Sagitta sp.
Individual number

8

112

29

15

12

52

1

9

1

39
Percentage

46.9

5

21.8

0.4

3.8

0.4

Sagitta sp. (No. 9) is a problematical young form which is $3.9 \mathrm{~mm}$ in length. Tail segment occupies $34.9 \%$ of the body length including the caudal fin. Body robust and opaque, being almost of uniform width. Lateral field rather narrow, muscles strong. Head of moderate size, neck distinct. Collarette practically absent, being found very faintly merely around the neck. No constriction at tail septum.

Anterior fin begins at the posterior end of the ventral ganglion. Posterior fin one and half as long as the anterior fin and lies more on the tail segment than on the trunk and broadest behind the septum. Distance between both fins very short. Rayless zone absent on either fin. The apparent shape of eye pigment very small and roundish. Corona ciliata of Type $\mathrm{C}$, beginning behind the eyes and stretching

1) Contributions from the Seto Marine Biological Laboratory, No. 242.

Publ. Seto Mar. Biol. Lab., IV (1), 1954. (Article 10) 
on the trunk nearly one and a half as long as the head. It has a conspicuous depression on each side. Intestinal diverticula distinct. Hooks 10-10; anterior teeth 4-4; posterior teeth 5-5. Wing of the vestibular ridge reaches the first tooth, notch as deep as to reach the third tooth. Both ovaries and testes quite immature. Epiderm thickened slightly just behind the posterior fin.

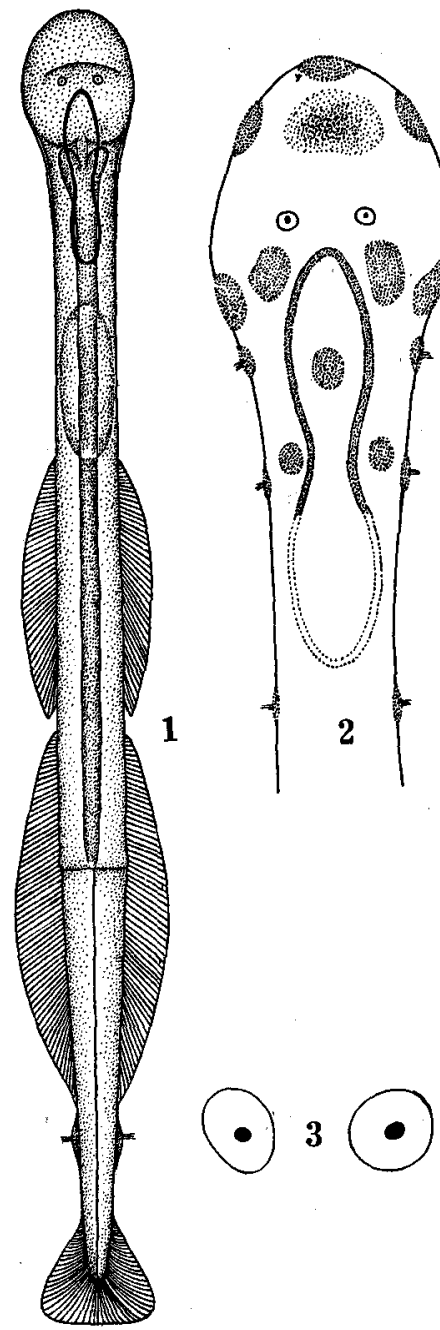

Fig. 18. Sagitta sp.

1...Entire animal, dorsal. $\times 33$

2...Anterior part of the body, dorsal. $\times 75$

3...Eyes. $\times 200$

Remarks: Sag. bedfordii DonCASTER resembles the present form at a glance. The former shows the formula $9-12 \frac{2-3}{2-3}$ at the body length near $4 \mathrm{~mm}$ (tail segment $36 \%$ ) which is the maximum for this species. The latter has more teeth along both rows, slightly longer anterior fin and corona ciliata and quite immature sexually at $3.9 \mathrm{~mm}$ body length.

Sag. parva OYE is a small species and superficially very like the present form. 
Even large individuals are less than $3.25 \mathrm{~mm}$ in length, tail segment $30 \%$ and armature formula is $6-8 \frac{3-5}{6-7}$. The present specimen has more hooks and quite immature sexually at even $3.9 \mathrm{~mm}$.

Young Sag. regularis seems to resemble the present specimen in the armament formula, but the former differs distinctly from the latter in the appearance of the collarette and the apparent shape of the eye pigment which is somewhat elongate in the former. Young Sag. neglecta and Sag. oceanica GraY ( = Sag. lacunae ToKIoKA) resemble the present specimen in the appearance of the collarette and in the outline of the eye pigment, but differ in the teeth formula. Young Sag. ferox and Sag. robusta (Sag. ai in Tokiok A 1942, p. 541) conform well with the present specimen, excepting in number of hooks and the shape of the corona ciliata and the eye pigment. Ten hooks are not yet recorded for these two species, eye pigment of the preset specimen seems too small for the two species. Corona ciliata of Type $\mathrm{C}$ is possible to occur on very young individuals of the species which are provided with the corona of Type B in grown state (TokiokA 1942, p. 540).

These comparisons seem to induce me to the conclusion that the present specimen may belong to a new form or rather represent a young individual of Sag. ferox or Sag. robusta.

Sag. enflata is the most dominant species in this collection, next Sag. serratodentata pacifica and followed by Sag. bipunctata and Sag. robusta. In a collection from the water surrounding the Palao Islands, Sag. enflata was the commonest species, next Sag. serratodentata pacifica and Sag. ferox and followed by Sag. regularis, Sag. neglecta and Pt. draco; in a small material from the Arafura Sea, Sag. enflata and Sag. bedoti f. minor were common and followed by Sag. robusta and Ktta. pacifica (Tokroka 1942).

It may be said safely that Sag. enflata is the commonest species and followed by Sag. serratodentata pacifica, Sag. ferox and Sag. robusta in the open sea water in the central Pacific. Sag. neglecta, Sag. regularis and Sag. bipunctata occur commonly, but not so abundant as the species mentioned above. Pt. draco and Ktta. pacifica are met with frequently, although they are rather few in number. Sag. bedoti occurred abundantly in the material from the Arafura Sea, but it is quite rare in other materials.

In the lagoon waters of the central Pacific, Sag. enflata and Sag. oceanica seem to be the commonest species. In lagoons of the Palao Islands there occur besides Sag. bedfordii and Sag. neglecta in a small number (Tokiona 1942). Most of Sag. neglecta recorded by R. MAURICE (1953) from lagoons of Takapato, Takaroa, Takume and Hikuem of the Tuamotu Islands are very probably Sag. oceanica. The material of the Great Barrier Reef Expedition collected inside the reef near Low Island consists chiefly of Sag. enflata, next Sag. neglecta and Sag. robusta and followed by Sag. bedoti, Sag. pulchra and Sag. serratodentata (BURFIEID 1950). 


\section{LITERATURE CITED}

BURField, S. T. (1950): Chaetognatha in Great Barrier Reef Exp. 1928-29, Sci. Rep., Vol. V, No. 8, pp. 459-473.

GrAY, B. B. (1930): Chaetognatha from the Society Islands, Proc. Roy. Soc. Queensland Vol. $42(6)$.

MAURICE, R. (1953): Quelques renseignements sur le plankton des lles Tuamotu, Bull. Mus. Nation. Hist. Nat., Tom. XXV, 2e Sér., pp. 456-462.

TокіокA, T. (1942): Systematic studies of the plankton organisms occurring in Iwayama Bay, Palao. III. Chaetognaths from the Bay and adjacent waters, Palao Trop. Biol. St. Studies, Vol. II, No. 3, pp. 527-548, Pls. V-VII, Figs. 1-11. 